PRACE GEOGRAFICZNE

zeszyt 156, 2019, 55-78

doi: 10.4467/20833113PG.19.003.10307

Instytut Geografii i Gospodarki Przestrzennej UJ

Wydawnictwo Uniwersytetu Jagiellońskiego

\title{
CZYNNIKI GEOGRAFICZNE WARUNKUJĄCE AKTYWNOŚĆ TURYSTYCZNA I WYBÓR DESTYNACJI TURYSTYCZNYCH CHICAGOWSKIEJ POLONII
}

\author{
Kamila Ziótkowska-Weiss
}

\section{Geographical factors conditioning the activity and tourist destinations of Chicago's Polonia}

\begin{abstract}
The main objective of the article is to present geographical factors conditioning the activity and tourist destinations among Chicago's Polonia. The following aspects were emphasized among these factors: location (climate, weather, exotics of the place), accessibility of transport, travel time, tourist attractions (unspoilt nature, quiet, peace), place of residence of the respondents. The objective of research was to check whether the place of residence influences the frequency of tourist trips and the choice of tourist destinations of Chicago's Polonia as well. The method of diagnostic survey in the form of surveys among Chicago's Polonia in the total number of 1014 in the Polish and English language is presented in the article. The study includes results of the research which confirm that people living outside the city of Chicago (in the suburbs) travel more frequently than people living in Chicago. The relaxation of people living outside Chicago lasts longer during the year than the relaxation of people living in Chicago as well as people living outside Chicago choose foreign journeys more frequently than people who live in Chicago.
\end{abstract}

Keyword: geographical factors, Chicago, Polonia, tourism

Zarys treści: Głównym celem artykułu jest przedstawienie czynników geograficznych warunkujących aktywność turystyczną oraz wybór destynacji turystycznych wśród chicagowskiej Polonii poza ich miejscem zamieszkania. Wśród tych czynników wyróżniono takie aspekty 
jak: lokalizacja miejsca wypoczynku (klimat, pogoda, egzotyka miejsca), dostępność komunikacyjna, czas dojazdu, walory turystyczne (nieskażona przyroda, cisza, spokój) oraz miejsce zamieszkania badanych. Celem badania było również sprawdzenie, czy miejsce zamieszkania wpływa na częstość wyjazdów turystycznych oraz na wybór destynacji turystycznych Polonii chicagowskiej. W artykule zostanie zaprezentowana metoda sondażu diagnostycznego w postaci badań ankietowych wśród Polonii w liczbie 1014 w języku polskim i angielskim. W opracowaniu zostaną przedstawione wyniki badań, które mówią o tym, że osoby mieszkające poza miastem Chicago (na przedmieściach) częściej podróżują niż osoby mieszkające w Chicago. Wypoczynek osób mieszkających poza miastem Chicago w ciągu roku trwa dłużej niż osób mieszkających w Chicago, a także częściej wybierają oni zagraniczny urlop.

Stowa kluczowe: czynniki geograficzne, Chicago, Polonia, turystyka

\section{Wprowadzenie}

Potrzeba poznania kazała człowiekowi w różnych okresach rozwoju cywilizacji podejmować często ryzykowne podróże, których efektem były opisy odkrywanych obszarów, będące zachętą do odwiedzania ich przez innych, a następnie podbijania i zagospodarowywania (Liszewski 2005). Tym odkrywaniem i opisem świata, na różnym poziomie i w różnej skali, w sposób bardziej uporządkowany zajmowała się i nadal to robi geografia, z którą związane były początki turystyki (Liszewski 2003). Gdyby nie zróżnicowanie geograficzne świata (przyrodnicze, kulturowe, gospodarcze, cywilizacyjne i inne), sens odbywania dalekich podróży byłby znacznie ograniczony, a masowość przemieszczeń nie miałaby większego uzasadnienia. Tak więc czynnik geograficzny był i jest nadal (mimo ogromnego poszerzenia celów wyjazdów) istotnym warunkiem rozwoju zjawiska nazywanego dziś turystyką (Liszewski 2009).

W XXI w. zjawiskiem powszechnie występującym wśród mieszkańców miast jest wzrost zapotrzebowania na wypoczynek. Jak podaje Liszewski (1995), to właśnie turystyczna ruchliwość przestrzenna mieszkańców miast stanowi jeden z ważniejszych mierników rozwoju cywilizacyjnego społeczeństw. Ponad 60\% Polonii mieszkającej w Wielkiej Metropolii Chicagowskiej, przebywając na co dzień w sztucznym środowisku i w warunkach ciasnoty urbanizacyjnej (Sakson 2007), w krajobrazie odznaczającym się monotonią i szarością, narażonych jest nie tylko na osłabienie kondycji fizycznej, ale również zachwianie stabilności i odporności psychicznej. Stąd też bezpośredni kontakt z przyrodą, pozostającą poza obrębem cywilizacji technicznej, bądź też czasowa zmiana miejsca pobytu, z czym niewątpliwie związana jest turystyka, traktowane są jako antidotum na stres dnia codziennego. Wraz ze wzrostem zamożności Polonia mieszkająca w Wielkiej Metropolii Chicagowskiej coraz chętniej i częściej podróżuje (Fiń 2014).

Cechą charakterystyczną miasta Chicago jest jego różnorodność społeczna oraz bogactwo kulturowe, co w połączeniu z bardzo dobrze rozwiniętą bazą turystyczną, 
wysoką jakością usług oraz właściwą gospodarką turystyczną stanowi o dużej atrakcyjności tego miasta oraz obszarów je otaczających. Miasto-gigant, obszary zielone, drogi, parki, pomniki natury, wybrzeża, kąpieliska i inne formy na terenie Chicago są dobrze zagospodarowane po względem turystycznym. Jak zauważył Drzewiecki (1998),(...) szeroka dostępność społeczna rekreacji, a zwłaszcza turystyki, zapewnia w USA niezwykłe zróżnicowanie pod względem standardu i charakteru zagospodarowania przestrzennego oraz systemu ulg i ułatwień w korzystaniu z niego. Każdy turysta może wybrać rodzaj usług w zależności od swych upodobań i zamożności, nie odczuwając nigdy niedogodności z tytułu swej niższej pozycji materialnej. Można zaryzykować stwierdzenie, że nie ma w Stanach Zjednoczonych usługi turystycznej, która nie byłaby dostępna dla przeciętnego turysty, tyle że każdorazowo na innym poziomie (...)”. Zróżnicowanie kulturowe Stanów Zjednoczonych, ich duża powierzchnia, ogromna liczba mieszkańców, różnorodne walory turystyczne, liczne obiekty przyrodnicze, historyczne, antropogeniczne, doskonałe drogi, dobra reklama, rozbudowana baza noclegowa oraz wiele innych czynników determinują rozwój turystyki.

\section{Przegląd literatury omawianego zjawiska}

Aktywność turystyczna jest pojęciem, które coraz częściej można spotkać w różnych opracowaniach teoretycznych ekonomicznych, socjologicznych, psychologicznych, pedagogicznych i geograficznych. Przy jej definiowaniu napotyka się szereg trudności, które mogą wynikać z interdyscyplinarności tego zjawiska. Już samo pojęcie turystyki jest wieloznacznie określane w literaturze przedmiotu. Trudno jest również zdefiniować termin „aktywność”, który jest pojęciem bardzo ogólnym.

W literaturze przedmiotu pojęcie aktywność turystyczna definiuje się jako: „ogół czynności i działań ludzi, związanych z ich uczestnictwem w turystyce" (Alejziak 2009). Zagadnieniem aktywności turystycznej zajmują się m.in. Rogalewski (1974), Łopaciński (1988), Skórny (1989), Lubowicz (1996), Włodarczyk (1999), Delekta (2013).

Próbę typologizacji aktywności turystycznej podjął Alejziak (2009), który w ramach projektu badawczego realizowanego w latach 2006-2007 chciał wyjaśnić mechanizmy kształtowania się aktywności turystycznej. Efektem jego pracy jest wyodrębnienie trzech podstawowych typów uwarunkowań aktywności turystycznej: generatorów, aktywatorów i modyfikatorów. Generatory charakteryzuje autor jako czynniki, które wywołują aktywność turystyczną, powodując uświadomienie chęci podjęcia aktywności turystycznej przez człowieka i skłonności do zainicjowania w tym kierunku konkretnych działań. Nie jest to tożsame z decyzją o określonym wyjeździe. Do najistotniejszych generatorów badacz zalicza potrzeby turystyczne i motywy uprawiania turystyki. 
Drugim typem uwarunkowań aktywności turystycznej są aktywatory. Opisuje je jako czynniki umożliwiające podjęcie aktywności turystycznej, a więc takie, które powodują, że uświadomiona wcześniej dzięki generatorom chęć wyjazdu przeradza się w działania prowadzące do rzeczywistego podjęcia aktywności turystycznej. Do najważniejszych aktywatorów zalicza on czas wolny oraz wszystkie czynniki ekonomiczne (ceny usług turystycznych, dochód, podaż usług turystycznych i popyt na nie). Modyfikatory natomiast określa jako czynniki, które wpływają na kształt i charakter aktywności turystycznej. Jako najważniejsze modyfikatory aktywności turystycznej wymienia on: czynniki społeczno-kulturowe (np. styl życia, wpływ grup odniesienia), czynniki przyrodniczo-geograficzne (np. miejsce zamieszkania, klimat), biologiczne (np. stan zdrowia, płeć), niektóre czynniki ekonomiczne oraz wiele innych. Modyfikatory stanowią najliczniejszą grupę czynników, jednak, jak twierdzi autor tej typologii, mają one mniejszy wpływ na poziom aktywności turystycznej niż generatory i aktywatory. W zaproponowanej koncepcji wszystkie elementy pozostają ze sobą we wzajemnych relacjach, a dany czynnik może być generatorem, aktywatorem lub modyfikatorem, w zależności od sytuacji (Alejziak 2009).

Alejziak (2009) przedstawia również podział na czynniki wewnętrzne (subiektywne) oraz czynniki zewnętrzne (obiektywne). Do pierwszej grupy czynników wewnętrznych zalicza: potrzeby turystyczne, motywy uprawiania turystyki, wartości towarzyszące turystyce, postawy, aspiracje oraz czynniki irracjonalne. W drugiej grupie czynników zewnętrznych znajdują się: czas wolny, uwarunkowania ekonomiczne, biologiczne i zdrowotne, demograficzne, społeczno-kulturowe, przyrodniczo-geograficzne, technologiczne, polityczne oraz inne (podaż turystyczna, doświadczenie turystyczne, moda, środki masowego przekazu, marketing turystyczny).

Do jednych z najważniejszych problemów w badaniach migracji turystycznych należy obecnie zagadnienie destynacji turystycznych oraz ich uwarunkowań. Jest to współcześnie jedno z częściej opisywanych zagadnień w literaturze anglojęzycznej (m.in. Burkart, Medlik 1981; Travis 1989; Um, Crompton 1990; Boniface, Cooper 1994; French i in. 1995; Pearce 1995).

Niektórzy badacze, np. Parzych (2008), traktują pojęcie destynacji turystycznej jako synonim przestrzeni turystycznej, a ta z kolei opisywana jest m.in. przez Włodarczyka (2009) jako „przestrzeń turystyczna definiowana jako część przestrzeni geograficznej, obejmująca miejscowości, regiony o określonych walorach turystycznych środowiska geograficznego i walorach recepcyjnych, będących miejscem realizacji wyjazdów turystycznych”. W niniejszej pracy destynacja turystyczna jest rozumiana jako jednostka geograficzna (miasto, region, kraj, wyspa, stan), fragment przestrzeni turystycznej wybrany przez turystę jako miejsce docelowe podróży.

Na podstawie przeglądu literatury można powiedzieć, że kwestie geograficznych uwarunkowań aktywności turystycznej są podejmowane sporadycznie. Badania tego typu były przeprowadzone w Polsce w latach 80. XX w. w ramach Centralnego 
Programu Badań Podstawowych. Koncentrowały się raczej wokół obszarów recepcyjnych, z pominięciem obszarów emitujących ruch turystyczny (Deja 1986). W ostatnich latach o czynnikach geograficznych pisali Alejziak (2009) i Różycki (2006), jednakże swoich teoretycznych rozważań nie poparli badaniami empirycznymi.

Środowisko geograficzne może wpływać zarówno na cechy fizyczne, jak i psychiczne człowieka. Można więc założyć, że czynniki związane z charakterem środowiska przyrodniczego (miejsca zamieszkania) mają również wpływ na aktywność turystyczną (Deja 1986), a szczególne znaczenie może odgrywać tu atrakcyjność turystyczna tego środowiska.

Zależnościami pomiędzy czynnikami geograficznymi a aktywnością turystyczną zajmują się m.in. Meyer (2004) i Niezgoda (2006). Uważają one, że na szczególną uwagę zasługują te prace, które opisują trasy turystyczne prowadzące od miejsc stałego pobytu do miejsc recepcji, rozpoznając przy tym zmienne wpływające na wybór tras i destynacji turystycznych. Jak piszą Kowalczyk (1994) i Matczak (1992), o wyborze docelowych miejsc podróży turystycznych decydują przede wszystkim: krajobraz, klimat, woda (w tym dostęp do wód mineralnych), topografia, flora i fauna oraz walory antropogeniczne.

\section{Przebieg badań oraz zakres czasowy i przestrzenny badań empirycznych}

Zasadniczym obszarem prowadzonych badań była Wielka Metropolia Chicagowska, która została wybrana ze względu na najliczniej zamieszkującą ją grupę Polonii w Stanach Zjednoczonych (USA). Obszarem badań empirycznych było sześć hrabstw wchodzących w skład Wielkiej Metropolii Chicagowskiej: Cook, DuPage, Kane, Lake, McHenry, Will, oraz samo miasto Chicago, które leży w hrabstwie Cook.

Okres prowadzonych badań obejmował lata 2013 (badania pilotażowe) oraz 2014. Badania właściwe w USA prowadzone były w dwóch etapach. Etap pierwszy badań terenowych odbył się w dniach od 6 do 18 lutego 2014 r., natomiast drugi od 16 do 29 października 2014 r. Zadawane respondentom pytania odnoszące się do ich aktywności turystycznej i wyboru destynacji turystycznych dotyczyły ostatniego roku, ponieważ badanie skierowane było do osób, które podczas ostatniego roku przynajmniej raz wyjechały poza miejsce zamieszkania w celach turystycznych. Ta informacja zawarta była przy każdym zadawanym respondentom pytaniu.

Podczas badań zastosowano zarówno badania jakościowe, jak i ilościowe. Do badań ilościowych należy metoda sondażu diagnostycznego w postaci badań ankietowych. Podstawową bazę empiryczną stanowiły wyniki badań przeprowadzonych wśród Polonii mieszkającej w Wielkiej Metropolii Chicagowskiej. Część empiryczna badań miała formę sondażu diagnostycznego, przeprowadzonego metodą reprezentacyjną 
wśród populacji Polonii Wielkiej Metropolii Chicagowskiej. Badania właściwe objęły łącznie 1468 respondentów, z czego do analizy wykorzystano 1014 kwestionariuszy ankietowych, w tym $347 \mathrm{z}$ ankiety internetowej przeprowadzonej online, tzw. CASI (ang. Computer Assisted Self-Interviewing), w języku polskim i angielskim. Przeprowadzono badania ankietowe w sposób tradycyjny (papierowy), jak również częściowo za pomocą Internetu. Przyjęto, że nie wpływa to na zniekształcenie uzyskanych wyników badań. Osobiste dotarcie do wszystkich respondentów, aby badania były reprezentatywne, co do liczby osób w poszczególnych grupach wiekowych, nie było możliwe. W związku z tym jedyną możliwością dotarcia do respondentów była droga internetowa i próba uzyskania od nich odpowiedzi za pomocą internetowego kwestionariusza ankietowego w formie online.

Aby badana grupa była reprezentatywna, posłużono się danymi Census Bureau z 2013 r. oraz Yearbook of Immigration Statistic z 2013 r., na podstawie których obliczono strukturę płci i wieku osób w poszczególnych grupach wiekowych w stosunku do całej populacji Polonii zamieszkałej w Wielkiej Metropolii Chicagowskiej. Badania ankietowe prowadzone były wśród respondentów od 15. do 60. roku życia (i starszych). Konsulat Generalny Rzeczpospolitej Polskiej w Chicago podał, że w 2013 r. według zebranych danych, na terenie stanu Illinois przebywa około 1300000 Polaków. Są to Polacy, którzy mają uregulowany status pobytowy, ale jest też znaczna liczba osób (niemożliwa w żaden sposób do sprawdzenia, nawet przez służby imigracyjne lub przedstawicieli ambasady polskiej), którzy przebywają na terenie Illinois nielegalnie. Przyjęto, że zostanie przebadane 0,01\% Polonijnej populacji z liczby 1300000 , co dało 1300 osób. W badaniach nie uwzględniono najmłodszych przedstawicieli populacji, tj. dzieci w wieku 0-14 lat, które podróżują z rodzicami oraz z formalnych przyczyn nie byłyby w stanie poprawnie uzupełnić kwestionariusza ankietowego. Podział na siedem grup wiekowych podyktowany był chęcią dokonania dokładnej analizy aktywności turystycznej i wyboru destynacji turystycznych Polonii chicagowskiej. Podział na grupy wiekowe i strukturę płci respondentów zawiera tab. 1.

Jeśli chodzi o badania jakościowe, głównym narzędziem były pogłębiona analiza, wywiady oraz obserwacja uczestnicząca. Ich wyniki nie zostały omówione i scharakteryzowane w tym artykule, jednak należy podkreślić, że podczas przeprowadzonych badań również i ta metoda była stosowana. Jak pisze Stemplewska-Żakowicz (2010), pojęcie „metody jakościowe” można rozumieć na dwa sposoby: wąsko, jako specyficzną grupę metod badawczych i diagnostycznych w naukach społecznych (wywiad swobodny, obserwacja swobodna, znaczna część technik projekcyjnych), lub szeroko, jako odrębny paradygmat badawczy, opierający się na sobie właściwych założeniach ontologicznych, epistemologicznych i aksjologicznych.

Przedstawiciele nurtu jakościowego wolą przeprowadzać badania terenowe, poprzez wielogodzinne nieustrukturyzowane wywiady (Silverman 2007) lub obserwację uczestniczącą. Interesuje ich odpowiedź na pytanie „dlaczego” w większym 
Tab. 1. Struktura wieku i płeć respondentów

Table 1. Age structure and gender of the respondents

\begin{tabular}{|c|c|c|c|c|c|c|c|}
\hline \multirow{2}{*}{$\begin{array}{c}\text { Lp. } \\
\text { No. }\end{array}$} & \multirow{2}{*}{$\begin{array}{c}\text { Grupa wiekowa } \\
\text { Age group }\end{array}$} & \multicolumn{2}{|c|}{$\begin{array}{c}\text { Kobiety } \\
\text { Women }\end{array}$} & \multicolumn{2}{c|}{$\begin{array}{c}\text { Mężczyźni } \\
\text { Men }\end{array}$} & \multicolumn{2}{c|}{$\begin{array}{c}\text { Razem } \\
\text { Total }\end{array}$} \\
\cline { 5 - 9 } & & 0sób & $\%$ & osób & $\%$ & osób & $\%$ \\
\hline 1. & $15-19$ & 45 & 3,47 & 48 & 3,72 & 93 & 7,19 \\
\hline 2. & $20-24$ & 43 & 3,35 & 45 & 3,50 & 88 & 6,85 \\
\hline 3. & $25-29$ & 46 & 3,55 & 47 & 3,63 & 93 & 7,18 \\
\hline 4. & $30-39$ & 100 & 7,71 & 101 & 7,73 & 201 & 15,44 \\
\hline 5. & $40-49$ & 98 & 7,58 & 95 & 7,39 & 193 & 14,97 \\
\hline 6. & $50-60$ & 72 & 5,51 & 68 & 5,20 & 140 & 10,71 \\
\hline 7. & $\begin{array}{c}\text { Powyżej } 60 \\
\text { Above } 60\end{array}$ & 120 & 9,20 & 86 & 6,61 & 206 & 15,81 \\
\hline & $\begin{array}{c}\text { Razem } \\
\text { Total }\end{array}$ & 524 & 40,37 & 490 & 37,78 & 1014 & 78,15 \\
\hline
\end{tabular}

stopniu niż na pytanie „ile”. Badania jakościowe są dominującą metodą w antropologii, występują także w socjologii, teorii organizacji, psychologii (Konecki 2000). Badania jakościowe koncentrują się na „głębszej” analizie danego zjawiska. W badaniach jakościowych główny nacisk położony jest na to, aby za pomocą specjalnych technik badawczych lepiej i dokładniej zrozumieć analizowane zjawisko (Glaser, Strauss 2009).

W ramach badań sprawdzono, jak miejsce zamieszkania Polonii chicagowskiej wpływa na jej aktywność turystyczną oraz wybór destynacji turystycznych. Badania prowadzone były w obrębie Wielkiej Metropolii Chicagowskiej, w której skład wchodzi sześć hrabstw. Jednym z celów badania było sprawdzenie, jaka jest różnica w aktywności turystycznej osób mieszkających w mieście Chicago oraz tych zamieszkujących pozostałe hrabstwa, często uważane za droższe i bardziej ekskluzywne miejsca do zamieszkania niż Chicago. Zbadano, w jaki sposób miejsce zamieszkania chicagowskiej Polonii wpływa na wybór przez nią destynacji turystycznych oraz jaka jest częstość tych wyjazdów, jak długo trwają oraz jaki jest związek wyboru miejsca wypoczynku między osobami mieszkającymi w Chicago (często w blokach) a osobami mieszkającymi w pozostałych hrabstwach objętych badaniem 
(w prywatnych domach). Wśród czynników geograficznych warunkujących aktywność turystyczną i wybór destynacji turystycznych chicagowskiej Polonii wyróżniono takie aspekty jak:

- lokalizacja miejsca wypoczynku (klimat, pogoda, egzotyka miejsca),

- dostępność komunikacyjna,

- czas dojazdu,

- walory turystyczne (nieskażona przyroda, cisza, spokój),

- miejsce zamieszkania badanych.

Sprawdzono, czy miejsce zamieszkania respondentów jest istotnym wskaźnikiem dla Polonii chicagowskiej, który wpływa na aktywność turystyczną oraz wybór przez nich destynacji turystycznych. Tym samym postawione zostały hipotezy badawcze mówiące o tym, że miejsce zamieszkania respondentów w Wielkiej Metropolii Chicagowskiej wpływa na:

- częstość wyjazdów,

- długość ich trwania,

- wybór miejsca wypoczynku,

- wybór destynacji turystycznej.

W celu zidentyfikowania różnic i podjęcia próby odpowiedzi na postawione hipotezy, posłużono się testem niezależności chi-kwadrat $\left(\chi^{2}\right)$, który daje możliwość określenia istotności statystycznej dla związku pomiędzy dwiema zmiennymi mierzonymi na skali nominalnej (danych jakościowych). Test niezależności chi-kwadrat $\left(\chi^{2}\right)$ opiera się na porównywaniu liczebności odpowiedzi uzyskanych w badaniach z liczebnościami, których można oczekiwać przy założeniu, że między analizowanymi zmiennymi nie ma żadnego związku. Podstawowymi wartościami obliczanymi w omawianym teście są: chi-kwadrat $\left(\chi^{2}\right)$, stopień swobody (df) oraz poziom istotności statystycznej (alfa). Elementarne znaczenie dla wnioskowania ma wartość „alfa”, która określa prawdopodobieństwo uzyskania danego efektu w próbie, gdyby tego efektu nie było w populacji (Blalock 1987). Wskaźnik ten służy do oceny tego, czy uzyskany wynik jest statystycznie istotny. W prezentowanej pracy przyjęto założenie, podobnie jak w większości opracowań z tego zakresu, że wynik istotny statystycznie to taki, dla którego wartość „alfa” jest mniejsza od 0,05. Aby zbadać siłę związku, wykorzystano również w badaniach statystycznych współczynnik V Cramera. Stosuje się go, jeśli mamy przynajmniej jedną zmienną nominalną (Sojka 2003).

\section{Model uwarunkowań aktywności turystycznej oraz wyboru destynacji turystycznych}

Na potrzeby badań skonstruowano model uwarunkowań aktywności turystycznej oraz wyboru destynacji turystycznych. Uwarunkowania te podzielono na 
uwarunkowania zewnętrzne i wewnętrzne. Znając specyfikę Polonii mieszkającej w Wielkiej Metropolii Chicagowskiej, został uwzględniony szereg czynników, które wzajemnie na siebie oddziaływają oraz wpływają na jej aktywność turystyczną oraz wybór destynacji turystycznych. W uwarunkowaniach wewnętrznych wyróżniono czynniki demograficzne, społeczne, kulturowe oraz ekonomiczne. W uwarunkowaniach zewnętrznych wyróżniono natomiast czynniki prawne i polityczne, czynniki geograficzne oraz organizację turystyki.

Charakteryzując czynniki wewnętrzne, jak i zewnętrzne, wzięto pod uwagę wiele wskaźników, które zbadano i określono, w jakim stopniu mają one wpływ na aktywność turystyczną i wybór destynacji turystycznych Polonii chicagowskiej. Zostały one zestawione i przypisane do odpowiedniego czynnika. Do czynników geograficznych zaliczone zostały: lokalizacja miejsca wypoczynku, dostępność komunikacyjna, czas dojazdu do miejsca wypoczynku, walory turystyczne (nieskażona przyroda, cisza, spokój) oraz miejsce zamieszkania respondentów. Wszystkie te wskaźniki zostaną omówione w niniejszym artykule.

Omawiając uwarunkowania aktywności turystycznej i wyboru destynacji turystycznych Polonii chicagowskiej oraz opisując poszczególne cechy, które na nie wpływają, przedstawiono ich ogólną charakterystykę dla wszystkich grup wiekowych łącznie.

Badając cechy wpływające na aktywność turystyczną oraz wybór destynacji turystycznych przez chicagowską Polonię, poproszono respondentów o wybranie z puli różnych czynników trzech ich zdaniem najważniejszych. W tym miejscu użyte zostało słowo „czynnik”, jako synonim cechy, gdyż w kwestionariuszu ankietowym dla przejrzystości i lepszego zrozumienia przez ankietowanych został zastosowany wyraz „czynnik”, a nie „cecha”. Każda z ankietowanych osób zaznaczyła po trzy, według niej, najistotniejsze czynniki, które decydują o jej aktywności turystycznej oraz o wyborze destynacji turystycznych. Po otrzymaniu wyników poszczególnym czynnikom przyporządkowano rangi.

Wśród możliwych odpowiedzi znalazły się czynniki geograficzne, które często wybierane były przez respondentów. Pierwsze miejsce we wszystkich sześciu grupach wiekowych zajęła „cena, koszt wyjazdu”. Spośród 1014 ankietowanych takich odpowiedzi udzieliło aż 48,2\%. Na drugim miejscu wśród odpowiedzi znalazło się zagospodarowanie turystyczne, na które wskazało 34,8\% respondentów. Trzecim najistotniejszym czynnikiem wpływającym na aktywność turystyczną oraz wybór destynacji turystycznych według ankietowanych jest moda (31,2\%). Na kolejnych miejscach odpowiednio znalazły się: atrakcje turystyczne w danym miejscu $(28,9 \%)$, czas dojazdu (27\%), warunki do uprawiania różnych sportów turystyki aktywnej, np. narciarstwa, pływania, żeglugi, birds, whale and dolphin watching (26,8\%), klimat, pogoda panująca w wybranym przez respondentów obszarze recepcji turystycznej (20,1\%), poczucie bezpieczeństwa w danym miejscu (19,7\%), rekomendacja miejsca wypoczynku przez znajomych $(12,3 \%)$, walory turystyczne (nieskażona przyroda, 
cisza, spokój) (10,8\%). Mniej ankietowanych wskazało: ofertę kulturalną w danym miejscu (10,5\%), życzliwość mieszkańców danego regionu (9,8\%), chęć poszerzenia wiedzy o miejscu wybranym na wypoczynek (7,5\%). Najmniej osób udzieliło odpowiedzi, że możliwość zrobienia zakupów (3,6\%) jest według nich jednym z trzech czynników, który decyduje o ich aktywności turystycznej oraz wyborze przez nich destynacji turystycznych. To samo miejsce wypoczynku co roku wybiera 4,2\% ankietowanych. Rozkład odpowiedzi na to pytanie przedstawia ryc. 1.

\section{Czynniki geograficzne warunkujące aktywność turystyczną i wybór destynacji turystycznych chicagowskiej Polonii}

Czynnikiem geograficznym, który wpływa na aktywność turystyczną jest urbanizacja. Pedro (2006) podkreśla, że aktywność turystyczna rośnie wraz ze wzrostem liczby mieszkańców. Mając na uwadze rodzaj jednostki osadniczej, można śmiało powiedzieć, że osoby zamieszkujące miasta odznaczają się wyższym poziomem aktywności turystycznej niż mieszkańcy wsi (Rocznik Statystyczny Rzeczypospolitej Polskiej GUS 2013; Berlińska-Dzikowska i in. 1987). Przyczyn takiej sytuacji należy upatrywać w nakładaniu się na siebie wielu czynników niekorzystnie wpływających na aktywność turystyczną mieszkańców wsi, np. mniejsza ilość czasu wolnego, niższy poziom wykształcenia i dochodów (Alejziak 1990). Niezależnie jednak od rodzaju jednostki osadniczej czynnikiem, który zdecydowanie różnicuje aktywność turystyczną ludności jest wielkość jednostek przestrzennych (Wasiakowa 1982). Badania nad zależnościami między gęstością zaludnienia a aktywnością turystyczną pokazują, że większa gęstość zaludnienia wpływa na wzrost aktywności turystycznej (Alejziak 2009). Aktywność turystyczna wykazuje duże zróżnicowanie także w odniesieniu do regionów. Wynika to z różnic w zakresie poziomu rozwoju społeczno-gospodarczego regionów, stanu infrastruktury turystycznej i występowania walorów turystyczno-rekreacyjnych (Nowakowska 1989).

Badania aktywności turystycznej w kontekście wielkości miast pokazują, że procent osób uczestniczących w turystyce zwiększa się wraz ze wzrostem liczby mieszkańców miast. W ocenie Raboteura (za: Alejziak 2009) wpływ miejsca zamieszkania uwidacznia się w trzech aspektach uczestnictwa w turystyce: stopie aktywności turystycznej, długości wyjazdów oraz charakterze destynacji turystycznych. Badacz ten na podstawie analizy badań przeprowadzonych w wielu krajach oszacował średnie wartości stopy aktywności turystycznej w zależności od liczby mieszkańców. Kształtują się one następująco:

- powyżej 1 mln mieszkańców: 70-80\%,

- od 100 tys. do 1 mln mieszkańców: 50-70\%,

- od 50 tys. do 100 tys. mieszkańców: 40-50\%, 


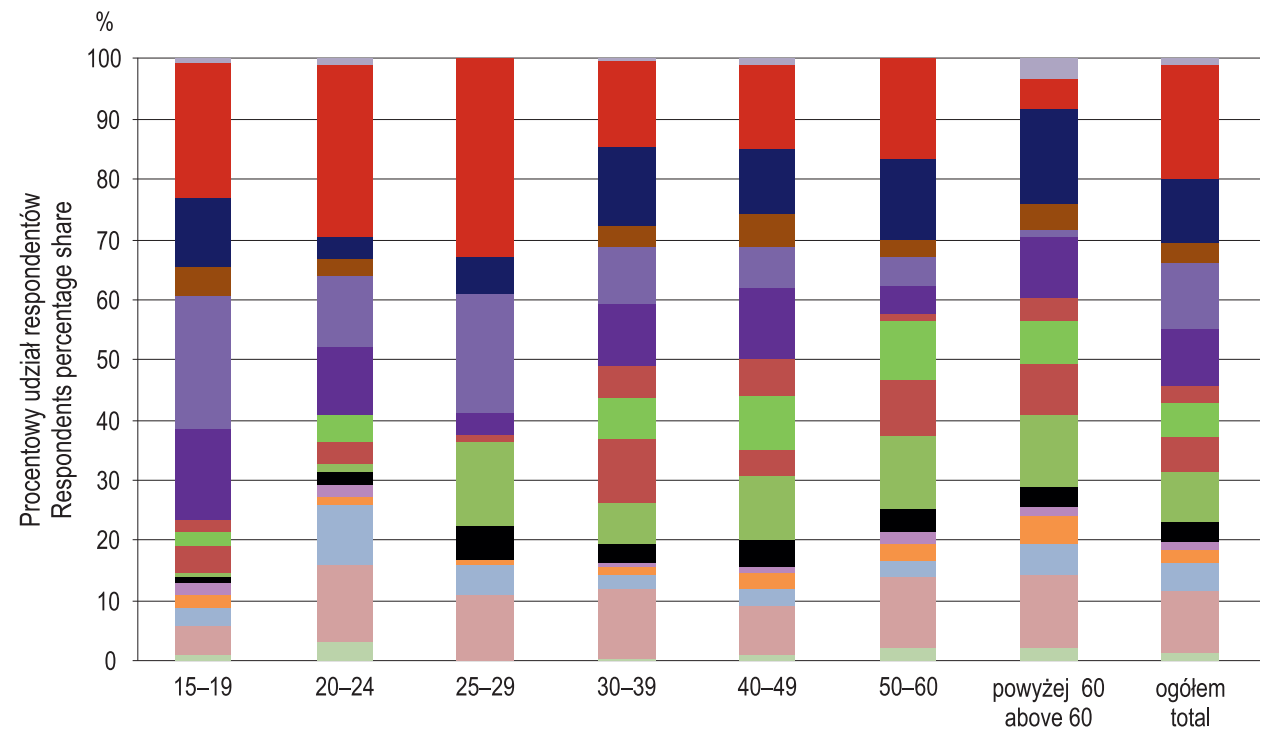

Wiek respondentów / Respondents age

Inne / Other

Cena, koszt wyjazdu / Price, cost of the trip

Zagospodarowanie turystyczne / Tourist development

Nieskażona przyroda, cisza, spokój / Unspoilt nature, silence, peace

Warunki do uprawiania rożnych sportów / turystyki / Conditions for practising various sports / tourism

Atrakcje turystyczne / Tourist attractions

Życzliwość mieszkańców miejscowości recepcyjnej / Kindness of the inhabitants of the hosting town

Poczucie bezpieczeństwa $w$ danym miejscu / The sense of security in a particular place

Klimat, pogoda, egzotyka miejsca / Climate, weather, exotic character of the place

Czas dojazdu / Time of arrival

Oferta kulturalna / Cultural offer

Możliwość zrobienia zakupów / Possibility of doing shopping

Chęć poszerzenia wiedzy o danym miejscu / Broadening knowledge about a particular place

Rekomendacja znajomych / Recommendation of friends

Moda / Fashion

Te same sprawdzone przez siebie miejsca / The same known places

Ryc. 1. Czynniki decydujące o aktywności turystycznej oraz wyborze destynacji turystycznej przez Polonię chicagowską [ $\mathrm{n}=1014]$

Fig. 1. Factors conditioning the tourist activity and choice of tourist destinations of Chicago's

Polonia [n=1014] 


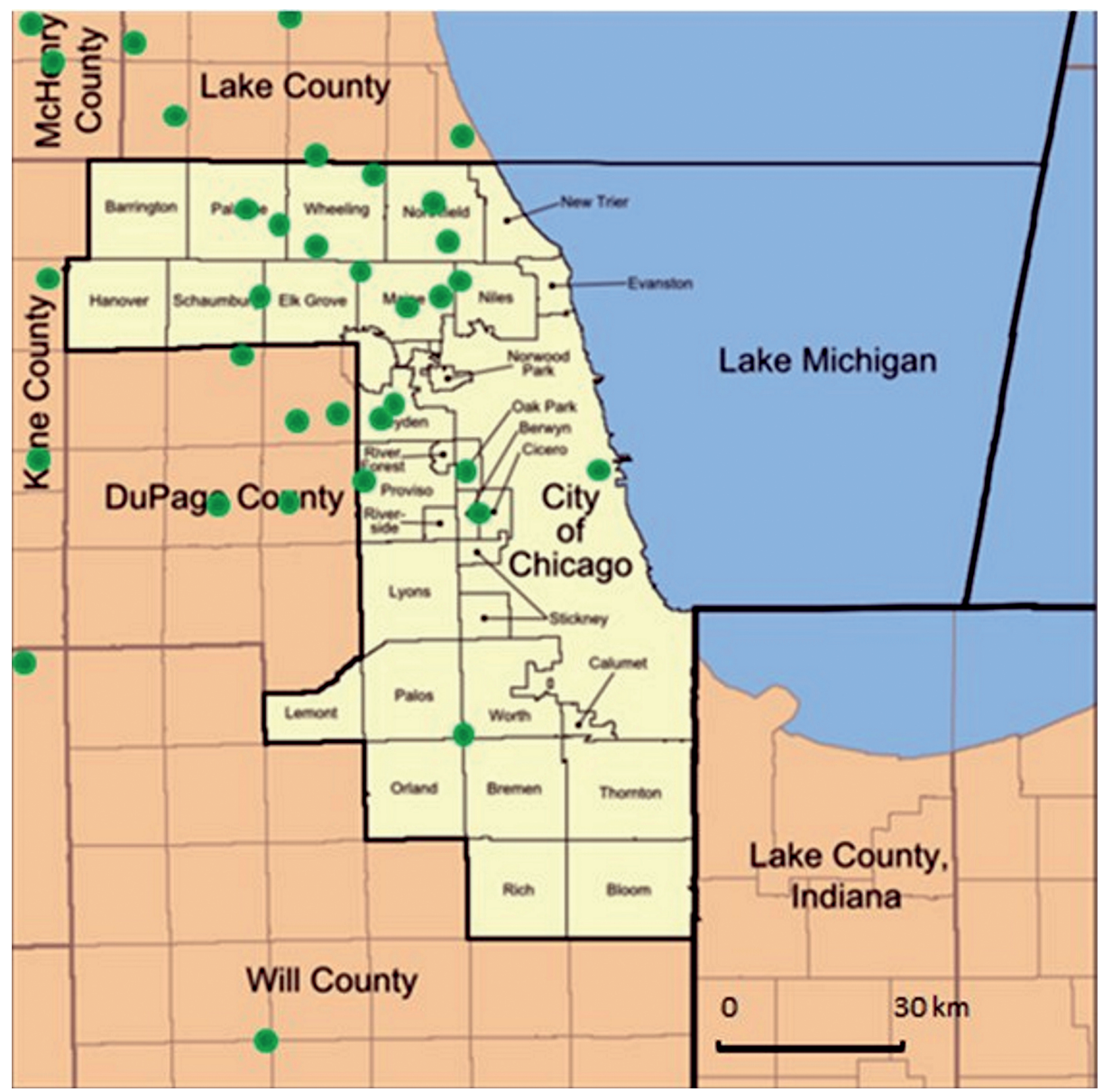

Ryc. 2. Miejsce zamieszkania ankietowanych

Fig. 2. Place of residence of the respondents

Objaśnienia: • miejsce zamieszkania respondentów, o granica hrabstwa Cook.

Explanations: • place of residence of the respondents, o boundary of Cook county.

Źródto: opracowanie własne na podkładzie graficznym pochodzącym z Commons Wikimedia

[https://commons.wikimedia.org/wiki/File:Map_of_Cook_County_Illinois_showing_townships.png].

Source: own study on a graphic basis derived from Commoms Wikimedia [https://commons.wikimedia. org/wiki/File:Map_of_Cook_County_Illinois_showing_townships.png]. 
- od 20 tys. do 50 tys. mieszkańców: 30-40\%,

- poniżej 20 tys. mieszkańców: 15-30\%.

Ludność USA jest konglomeratem osób o różnym pochodzeniu etnicznym, rasowym, wyznaniowym oraz o różnym statusie ekonomicznym (Kymlicka 1999). Te wszystkie czynniki powodują, że społeczeństwo w USA jest wielokulturowe i bardzo zróżnicowane. Przez pokolenia Polonia amerykańska poddawana była wielu istotnym przemianom ekonomicznym, demograficznym, kulturalnym, politycznym i społecznym. Wymienione czynniki mogą przyczyniać się do procesu, jakim jest wybór lub zmiana miejsca zamieszkania (Dziekońska 2008). W literaturze przedmiotu najważniejsze jest przekonanie, że zmiana miejsca zamieszkania, będąca skutkiem emigracji, bardzo często jest przyczyną zmian w usytuowaniu społecznym jednostek, jak i całych grup społecznych (Dziekońska 2008).

Kwestią dotyczącą problematyki przemian zbiorowości etnicznych oraz liczebnością Polonii w USA zajmują się głównie Rokicki (1989; 1992), Iglicka (2008) i Fiń (2014). Od wielu lat Polacy, którzy nie chcą na stałe mieszkać w samym mieście Chicago, a chcąc przebywać względnie blisko miasta, przeprowadzają się na tereny podmiejskie, tzw. suburbia. Jak wynika ze statystyk, Polacy mieszkają w całym stanie Illinois. Jest jednak kilka obszarów o większym natężeniu ludności o polskich korzeniach. W ostatnich dziesięcioleciach zaobserwowano zjawisko ucieczki majętniejszej części ludności miasta na jego przedmieścia. Jak spostrzegł Babiński (2012), Polacy „mają lepszą pracę, więcej zarabiają i zazwyczaj przenoszą się na bardziej zamożne przedmieścia, gdzie wartość domów znacznie przekracza średnią krajową". Powodem przeprowadzki na przedmieścia Chicago są również niższe koszty życia (mniejsze podatki), lepsze warunki zamieszkania oraz bezpieczeństwo. W centrum metropolii mieszkają ludzie młodsi, podczas gdy w suburbiach żyje głównie ludność zamożniejsza, ogólnie starsza. Często jednak już pierwsze pokolenie imigrantów wybiera przedmieścia na miejsce swojego osiedlenia (Paral 2004). Zamieszkują oni przeważnie północno-zachodnie przedmieścia, takie jak: Niles, Des Planes, Park Ridge, Norridge, Naperville. Nie wszędzie powstały polskie parafie, niemniej jednak coraz więcej jest tam polskich restauracji, piekarni i sklepów.

W kwestionariuszu ankietowym respondenci poproszeni byli o podanie miejsca zamieszkania. Tab. 2 zawiera nazwy miejscowości i hrabstw, w których mieszkają ankietowani. Ryc. 2 przedstawia przestrzenne rozmieszczenie miejsc zamieszkania respondentów.

Spis Census Bureau (2013) nie uwzględnia informacji, ilu Polaków mieszka w poszczególnych miejscowościach na terenie Wielkiej Metropolii Chicagowskiej. W związku z tym nie ma możliwości udokumentowania proporcjonalnego doboru próby w danym hrabstwie. Tab. 2 przedstawia spis miejscowości, z których pochodzili respondenci biorący udział w badaniu. 
Tab. 2. Miejsce zamieszkania respondentów

Table 2. Place of residence of the respondents

\begin{tabular}{|c|c|c|c|}
\hline $\begin{array}{l}\text { Lp. } \\
\text { No. }\end{array}$ & $\begin{array}{l}\text { Miejscowość zamieszkania } \\
\text { Place of residence }\end{array}$ & $\begin{array}{l}\text { Hrabstwo } \\
\text { County }\end{array}$ & $\begin{array}{l}\text { Liczba ankietowanych } \\
\text { Number of respondents }\end{array}$ \\
\hline 1. & ADDISON & DuPage & 44 \\
\hline 2. & AURORA & Will & 25 \\
\hline 3. & ARLINGTON HEIGHTS & Cook & 6 \\
\hline 4. & BUFFALO GROVE & Lake & 6 \\
\hline 5. & BURBANK & Cook & 20 \\
\hline 6. & CHICAGO & Cook & 489 \\
\hline 7. & CICERO & Cook & 19 \\
\hline 8. & DES PLAINES & Cook & 12 \\
\hline 9. & ELGIN & Kane & 12 \\
\hline 10. & ELK GROVE & DuPage & 4 \\
\hline 11. & ELMHURST & DuPage & 13 \\
\hline 12. & ELWOOD & Will & 13 \\
\hline 13. & GENEVA & Kane & 8 \\
\hline 14. & GLENVIEW & Cook & 18 \\
\hline 15. & HARVARD & McHenry & 3 \\
\hline 16. & HARWOOD HEIGHTS & Cook & 30 \\
\hline 17. & HIGHLAND PARK & Lake & 2 \\
\hline 18. & LAKE ZURICH & Lake & 7 \\
\hline 19. & LOMBARD & DuPage & 30 \\
\hline 20. & ELWOOD & Cook & 13 \\
\hline 21. & MORTON GROVE & Cook & 4 \\
\hline 22. & MOUNT PROSPECT & Cook & 5 \\
\hline 23. & MUNDELEIN & Lake & 4 \\
\hline 24. & NILES & Cook & 28 \\
\hline 25. & NORRIDGE & Cook & 10 \\
\hline 26. & NORTHBROOK & Cook & 36 \\
\hline 27. & OAK PARK & Cook & 2 \\
\hline
\end{tabular}




\begin{tabular}{|c|l|l|c|}
\hline $\begin{array}{c}\text { Lp. } \\
\text { No. }\end{array}$ & $\begin{array}{c}\text { Miejscowość zamieszkania } \\
\text { Place of residence }\end{array}$ & $\begin{array}{c}\text { Hrabstwo } \\
\text { County }\end{array}$ & $\begin{array}{c}\text { Liczba ankietowanych } \\
\text { Number of respondents }\end{array}$ \\
\hline 28. & ORLAND PARK & Cook & 8 \\
\hline 29. & PALATINE & Cook & 21 \\
\hline 30. & PARK RIDGE & Cook & 26 \\
\hline 31. & PROSPECT HEIGHTS & Cook & 2 \\
\hline 32. & RICHMOND & DuPage & 5 \\
\hline 33. & ROSELLE & Cook & 33 \\
\hline 34. & SCHAUMBURG & Cook & 13 \\
\hline 35. & SCHILLER PARK & Lake & 7 \\
\hline 36. & WAUCONDA & DuPage & 11 \\
\hline 37. & WHEATON & Cook & 1014 \\
\hline 38. & WHEELING & Cook & 4 \\
\hline & Ogółem & & \\
\hline
\end{tabular}

Osoby biorące udział w badaniu $(\mathrm{n}=1014)$ mieszkają w 38 miejscowościach zlokalizowanych na terenie Wielkiej Metropolii Chicagowskiej, w tym 489 osób w Chicago (48,2\%), a pozostałe 525 osób $(51,8 \%)$ na przedmieściach miasta Chicago. Najliczniejsza grupa osób, 329 (32,4\%), mieszka w hrabstwie Cook (na terenie którego znajduje się samo miasto Chicago). Tak duża liczba osób objęta badaniem, która mieszka w hrabstwie Cook, wiąże się zapewne z tym, że hrabstwo to jest drugim pod względem liczby ludności hrabstwem w Stanach Zjednoczonych (po hrabstwie Los Angeles w Kalifornii). W jego granicach znajduje się miasto Chicago i liczne przedmieścia. Hrabstwo Cook ma więcej członków Partii Demokratycznej niż jakiekolwiek inne hrabstwo stanu i jest jednym z czołowych demokratycznych hrabstw w Stanach Zjednoczonych (Appleberg 1993). Hrabstwem, którego mieszkańcy stanowili liczną grupę w badaniach, jest hrabstwo DuPuge, gdzie mieszka 107 osób (10,6\%). Ankietowani pochodzący z hrabstwa DuPuge mieszkają m.in. w takich miejscowościach, jak: Addison, Elk Grove, Lombard, Elmhurst i Roselle. Następne pod względem liczby osób biorących udział w badaniu jest hrabstwo Will, gdzie mieszka 38 osób (3,7\%), przede wszystkim w miastach Elwood oraz Aurora. W hrabstwie Lake, uważanym za jedno z najdroższych miejsc w Wielkiej Metropolii Chicagowskiej, mieszka 26 osób (2,6\%), które wypełniły kwestionariusz ankietowy. Według danych statystycznych z 2000 r. hrabstwo to znajduje się na 31. miejscu w kraju pod względem dochodu na jednego mieszkańca (Census Bureau, 2000). Osoby 
z następujących miejscowości: Buffalo Grove, Highland Park, Lake Zurich, Mundelein oraz Wauconda, wchodzących w skład hrabstwa Lake, wzięły udział w badaniu. $\mathrm{Z}$ dwóch pozostałych hrabstw, tj. Kane oraz McHenry, łącznie w badaniu wzięło udział 25 osób, w tym 5 z hrabstwa McHenry (0,5\%) oraz 20 z hrabstwa Kane (2\%).

Jedną z zależności, jakie zostały zbadane w czynnikach geograficznych, był wpływ miejsca zamieszkania respondentów w Wielkiej Metropolii Chicagowskiej na częstość wyjazdów, długość ich trwania, wybór miejsca wypoczynku oraz wybór destynacji turystycznej. Pierwsza postawiona hipoteza zakłada, że osoby mieszkające poza miastem Chicago częściej niż osoby mieszkające w Chicago wybierają wyjazdy zagraniczne w ramach swojego urlopu. Tab. 3 przedstawia statystyczne obliczenia do tej hipotezy badawczej.

Dla poziomu istotności alfa=0,05 $\lambda 2$ alfa $<\lambda 2$, została odrzucona hipoteza zerowa, zatem można powiedzieć, że między kierunkiem wyjazdów a miejscem zamieszkania istnieje zależność korelacyjna. Postawiona hipoteza jest prawdziwa, a osoby mieszkające poza miastem Chicago częściej niż osoby mieszkające w Chicago wybierają zagraniczny urlop. Współczynnik V Cramera $(\mathrm{V}=0,11)$ świadczy o niskiej zależności między badanymi cechami.

Kolejna postawiona hipoteza zakłada, że osoby mieszkające poza miastem Chicago (na przedmieściach) podróżują częściej niż osoby mieszkające w mieście Chicago. Tab. 4 przedstawia statystyczne obliczenia do tej hipotezy badawczej.

Tab. 3. Miejsce zamieszkania a kierunek wyjazdów

Table 3. Place of residence vs. the direction of travels

\begin{tabular}{|c|c|c|c|}
\hline \multirow{2}{*}{$\begin{array}{l}\text { Kierunek wyjazdów } \\
\text { Direction of the tourist trip }\end{array}$} & \multicolumn{2}{|c|}{$\begin{array}{l}\text { Miejsce zamieszkania } \\
\text { Place of residence }\end{array}$} & \multirow{2}{*}{$\begin{array}{l}\text { Ogółem } \\
\text { Total }\end{array}$} \\
\hline & Chicago & $\begin{array}{l}\text { przedmieścia } \\
\text { suburbs }\end{array}$ & \\
\hline Wyjazdy krajowe / National trip & 194 & 190 & 384 \\
\hline Wyjazdy zagraniczne / Foreign trips & 106 & 173 & 279 \\
\hline $\begin{array}{l}\text { Wyjazdy zagraniczne - tylko do Polski } \\
\text { Foreign trips - to Poland only }\end{array}$ & 55 & 68 & 123 \\
\hline $\begin{array}{l}\text { Wyjazdy krótkoterminowe/weekendowe } \\
\text { Weekend trips }\end{array}$ & 134 & 94 & 228 \\
\hline Ogółem / Total & 489 & 525 & 1014 \\
\hline $\mathrm{df}$ & \multicolumn{3}{|c|}{$d f=3$} \\
\hline$\lambda 2$ & \multicolumn{3}{|c|}{23,27} \\
\hline$\lambda 2$ alfa & \multicolumn{3}{|c|}{7,81} \\
\hline
\end{tabular}


Tab. 4. Miejsce zamieszkania a częstość podróżowania

Table 4. Place of residence vs. the frequency of travels

\begin{tabular}{|c|c|c|c|}
\hline \multirow{2}{*}{$\begin{array}{l}\text { Częstość wyjazdów } \\
\text { Frequency of travels }\end{array}$} & \multicolumn{2}{|c|}{$\begin{array}{l}\text { Miejsce zamieszkania } \\
\text { Place of residence }\end{array}$} & \multirow{2}{*}{$\begin{array}{c}\text { Ogółem } \\
\text { Total }\end{array}$} \\
\hline & Chicago & $\begin{array}{l}\text { przedmieścia } \\
\text { suburbs }\end{array}$ & \\
\hline Raz w roku / Once a year & 139 & 226 & 365 \\
\hline 2-4 razy w roku / 2-4 times a year & 274 & 255 & 529 \\
\hline 5-8 razy w roku / 5-8 times a year & 41 & 29 & 70 \\
\hline Powyżej 8 razy w roku / Above 8 times a year & 35 & 15 & 50 \\
\hline Ogółem / Total & 489 & 525 & 1014 \\
\hline df & \multicolumn{3}{|c|}{$\mathrm{df}=3$} \\
\hline$\lambda 2$ & \multicolumn{3}{|c|}{30,24} \\
\hline 入2alfa & \multicolumn{3}{|c|}{7,81} \\
\hline
\end{tabular}

Dla poziomu istotności alfa $=0,05 \lambda 2$ alfa $<\lambda 2$ została odrzucona hipoteza zerowa, zatem można powiedzieć, że między częstością wyjazdów a miejscem zamieszkania istnieje zależność korelacyjna. Postawiona hipoteza badawcza jest prawdziwa, a osoby mieszkające poza miastem Chicago (na przedmieściach) podróżują częściej od osób mieszkających w Chicago. Współczynnik V Cramera $(V=0,12)$ świadczy o niskiej zależności między badanymi cechami.

Następna z hipotez badawczych zakładała, że wypoczynek osób mieszkających poza miastem Chicago (na przedmieściach) trwa w ciągu roku dłużej niż u osób mieszkających w Chicago. Tab. 5 przedstawia obliczenia statystyczne dotyczące tej hipotezy badawczej.

Dla poziomu istotności alfa $=0,05 \lambda 2$ alfa $<\lambda 2$ została odrzucona hipoteza zerowa, zatem można powiedzieć, że między długością trwania wyjazdów a miejscem zamieszkania istnieje zależność korelacyjna. Postawiona hipoteza badawcza jest prawdziwa i potwierdza, że wypoczynek osób mieszkających poza miastem Chicago w ciągu roku trwa dłużej niż osób mieszkających w Chicago. Współczynnik V Cramera $(\mathrm{V}=0,15)$ świadczy o dość niskiej zależności między badanymi cechami.

Ostatnia postawiona hipoteza badawcza zakłada, że osoby mieszkające w mieście Chicago jako miejsce wypoczynku wybierają wieś częściej niż osoby mieszkające poza miastem Chicago (na przedmieściach). Tab. 6 przedstawia obliczenia statystyczne dotyczące tej hipotezy badawczej.

Dla poziomu istotności alfa $=0,05 \lambda 2$ alfa $<\lambda 2$ została odrzucona hipoteza zerowa, zatem można powiedzieć, że między wyborem miejsca wypoczynku a miejscem 
Tab. 5. Miejsce zamieszkania a długość trwania wyjazdów

Table 5. Place of residence vs. duration of travels

\begin{tabular}{|l|c|c|c|}
\hline \multirow{2}{*}{$\begin{array}{c}\text { Długość trwania wyjazdów } \\
\text { Duration of travels }\end{array}$} & \multicolumn{2}{|c|}{$\begin{array}{c}\text { Miejsce zamieszkania } \\
\text { Place of residence }\end{array}$} & \multirow{2}{*}{$\begin{array}{c}\text { Ogółem } \\
\text { Total }\end{array}$} \\
\cline { 2 - 3 } & Chicago & $\begin{array}{c}\text { przedmieścia } \\
\text { suburbs }\end{array}$ & 257 \\
\hline Tydzień / A week & 143 & 114 & 317 \\
\hline 2 tygodnie / 2 weeks & 179 & 138 & 249 \\
\hline 3 tygodnie / 3 weeks & 99 & 150 & 158 \\
\hline Miesiąc / A month & 48 & 110 & 33 \\
\hline Więcej / More & 20 & 13 & 1014 \\
\hline Ogółem / Total & 489 & 525 & \\
\hline df & & $\mathrm{df}=4$ & \\
\hline$\lambda 2$ & \multicolumn{3}{|c}{93,61} \\
\hline$\lambda 2$ alfa & \multicolumn{3}{|}{} \\
\hline
\end{tabular}

zamieszkania istnieje zależność korelacyjna. Postawiona hipoteza badawcza jest prawdziwa i potwierdza, że osoby mieszkające w mieście Chicago jako miejsce wypoczynku wybierają wieś częściej niż osoby mieszkające poza miastem Chicago (na przedmieściach). Współczynnik V Cramera $(\mathrm{V}=0,23)$ świadczy o dość niskiej zależności między badanymi cechami.

Do grupy czynników geograficznych mających duży wpływ na aktywność turystyczną i wybór destynacji turystycznych należą: klimat, warunki pogodowe oraz egzotyka miejsca. Przeglądu walorów środowiska przyrodniczego w turystyce i rekreacji w skali makro dokonał m.in. Kożuchowski (2005), a także autorzy tomu pod red. Młynarczyka i Zajadacz (2008). Autorzy ci wskazali walory poszczególnych składników tego środowiska. Zdaniem Kożuchowskiego (2005) najważniejszą rolę w uznaniu miejsca lub obszaru za atrakcyjny turystycznie w skali świata odgrywa klimat. To przecież temperatury powietrza i wody, wielkość opadów deszczu i śniegu, nasłonecznienie, wiatry i inne zjawiska atmosferyczne decydują o komforcie klimatycznym miejscowości lub regionu, a co za tym idzie o samopoczuciu człowieka i chęci jego zamieszkania lub pobytu czasowego. Warunki klimatyczne odegrały bardzo ważną rolę nie tylko w rozwoju starożytnych cywilizacji, lecz także współczesnej turystyki (rozwój turystyki na wybrzeżach i wyspach ciepłych mórz, w wysokich górach itd.).

W tym miejscu można zacytować spostrzeżenia Dziedzic (2000, s. 75), która pisze, że ,wśród czynników decydujących o wyjeździe wakacyjnym, przewidywana pogoda 
Tab. 6. Miejsce zamieszkania a wybór miejsca wypoczynku

Table 6. Place of residence vs. the choice of the place of relaxation

\begin{tabular}{|l|c|c|c|}
\hline \multirow{2}{*}{\begin{tabular}{c}
\multirow{2}{*}{$\begin{array}{c}\text { Wybór miejsca wypoczynku } \\
\text { Choice of the place of relaxation }\end{array}$} \\
\cline { 2 - 3 }
\end{tabular}} & \multicolumn{2}{|c|}{$\begin{array}{c}\text { Miejsce zamieszkania } \\
\text { Place of residence }\end{array}$} & $\begin{array}{c}\text { Ogółem } \\
\text { Total }\end{array}$ \\
\cline { 2 - 3 } $\begin{array}{l}\text { Centrum turystyczno-wypoczynkowe } \\
\text { Tourism and recreational center }\end{array}$ & 102 & $\begin{array}{c}\text { przedmieścia } \\
\text { suburbs }\end{array}$ & 219 \\
\hline Miasto / City & 47 & 117 & 63 \\
\hline Wieś / Countryside & 53 & 42 & 95 \\
\hline $\begin{array}{l}\text { Miejsce oddalone od siedzisk ludzkich } \\
\text { Place away from human settlements }\end{array}$ & 67 & 43 & 110 \\
\hline Miejscowość turystyczna / Tourist resort & 83 & 101 & 184 \\
\hline Ośrodek pielgrzymkowy / Pilgrimage center & 5 & 66 & 71 \\
\hline Obszar górski / Mountain area & 49 & 39 & 88 \\
\hline Morze / Sea & 53 & 65 & 118 \\
\hline Akwen śródlądowy (jeziora) / Lake & 18 & 7 & 25 \\
\hline Uzdrowiska / Spa & 0 & 15 & 15 \\
\hline $\begin{array}{l}\text { Dzikie obszary (np. pustynie) } \\
\text { Wilderness (e.g. desert) }\end{array}$ & 12 & 8 & 20 \\
\hline Inne miejsca / Other places & 0 & 6 & 6 \\
\hline Ogółem / Total & 489 & 525 & 1014 \\
\hline df & & 104,81 & \\
\hline$\lambda 2$ & & 19,68 & \\
\hline$\lambda 2 a l f a$ & & & \\
\hline
\end{tabular}

jest wymieniana na pierwszym miejscu przez prawie wszystkie grupy turystów”. Znaczenie warunków klimatyczno-pogodowych dla aktywności turystycznej jest szczególnie widoczne w krajach leżących w strefie klimatu umiarkowanego i zmiennego (Viner, Nichols 2006). Złe warunki atmosferyczne mogą spowodować zmiany planów podróży, zarówno w odniesieniu do terminów, jak i destynacji, a także mogą wywołać komplikacje na rynku turystycznym.

W ankiecie znalazło się pytanie dotyczące najistotniejszych czynników branych pod uwagę przy wyborze destynacji turystycznych przez ankietowanych. Jedną z możliwości odpowiedzi była „klimat, pogoda, egzotyka miejsca”, która zdaniem respondentów znalazła się na siódmym miejscu (20,1\%). Najwięcej takich odpowiedzi 
zostało udzielonych w grupie wiekowej 30-39 lat (10,4\%), 50-60 lat (9,0\%) oraz powyżej 60 lat (8,4\%). Mniejsze znaczenie, jeśli chodzi o pogodę, zauważalne jest w młodszej grupie wiekowej. Najmniej odpowiedzi padło wśród osób w przedziale wiekowym 25-29 lat (1,1\%), 20-24 lat (3,8\%) oraz 15-19 lat (4,3\%). Znaczenie czynników takich jak: klimat, pogoda, egzotyka miejsca, czas dojazdu oraz walory turystyczne (nieskażona przyroda, cisza, spokój) zostały przedstawione na ryc. 3.

Jednym z badanych aspektów były walory turystyczne (nieskażona przyroda, cisza, spokój). Tylko 10,8\% osób spośród ankietowanych wybrało ten wskaźnik jako jeden z trzech ważnych dla nich. Aspekt ten jest zupełnie nieistotny dla osób w grupie wiekowej 25-29 lat, ponieważ nikt z tych osób nie zaznaczył takiej odpowiedzi. Chęć odpoczynku wśród nieskażonej przyrody, w ciszy i spokoju wybrało 5,5\% osób w wieku 40-49 lat oraz 5\% osób w wieku 15-19 lat. Okazuje się, że dla osób starszych, podobnie jak dla osób w przedziale wiekowym 30-39 (3,3\%), nie jest to dominujący wskaźnik determinujący wybór destynacji turystycznych w tej grupie badawczej. Takich odpowiedzi padło 2,9\% w przedziale wiekowym 50-60 lat oraz 4,5\% wśród osób powyżej 60 lat. Wyniki zostały przedstawione na ryc. 3.

Dostępność komunikacyjna oraz czas dojazdu do miejsca wypoczynku jest kolejnym aspektem, który został wyróżniony i przebadany w czynnikach geograficznych. W XIX w. „iskrą”, która przyczyniła się do rozwoju turystyki stał się transport kolejowy, natomiast w XX w. był to transport samochodowy i lotniczy (Rettinger, Staszak 2010). Rozwój transportu spowodował gwałtowny wzrost mobilności społeczeństwa, znacznie ułatwiając oraz przyspieszając możliwość zmiany miejsca pobytu. Szybki rozwój środków komunikacji powoduje wzrost liczby wyjazdów turystycznych, ułatwia szybkość, dostępność, komfort przejazdu, bezpieczeństwo podróży oraz powoduje znaczne obniżenie kosztów przejazdu. Daje to możliwość dotarcia do niemal każdego wybranego miejsca. Rozwój infrastruktury drogowej, kolejowej oraz lotniczej skraca czas przemieszczania się, co ma wpływ na wydłużenie czasu przeznaczonego na wypoczynek. Gwałtowny rozwój przedsiębiorstw lotniczych oferujących niskokosztowe przedmioty pod koniec ubiegłego wieku znacznie przyczynił się do intensywniejszego rozwoju turystyki (Creaton 2004). Mówi się nawet o „demokratyzacji” pasażerskich podróży lotniczych. Jak zauważa Ziółkowska-Weiss (2013), budowa nowych, regionalnych lotnisk oraz modernizacja już istniejących znacznie skraca czas podróży, a tym samym wydłuża wypoczynek. Rozwój portów lotniczych przyczynia się do powstawania nowych obiektów towarzyszących i świadczących usługi korzystającym z lotnisk. Zdaniem Milewskiego (2008) bardzo istotnym czynnikiem rozwoju ruchu turystycznego w obecnych czasach stał się rozwój oraz zastosowanie do masowych przewozów pasażerskich transportu lotniczego.

Najczęściej wybieranymi przez chicagowską Polonię środkami lokomocji są samochód $(50,6 \%)$ oraz samolot $(43,9 \%)$. Pozostałe środki transportu nie odgrywają większej roli. Zadziwiająco mało osób wskazało prom, jako środek lokomocji. Takiej 


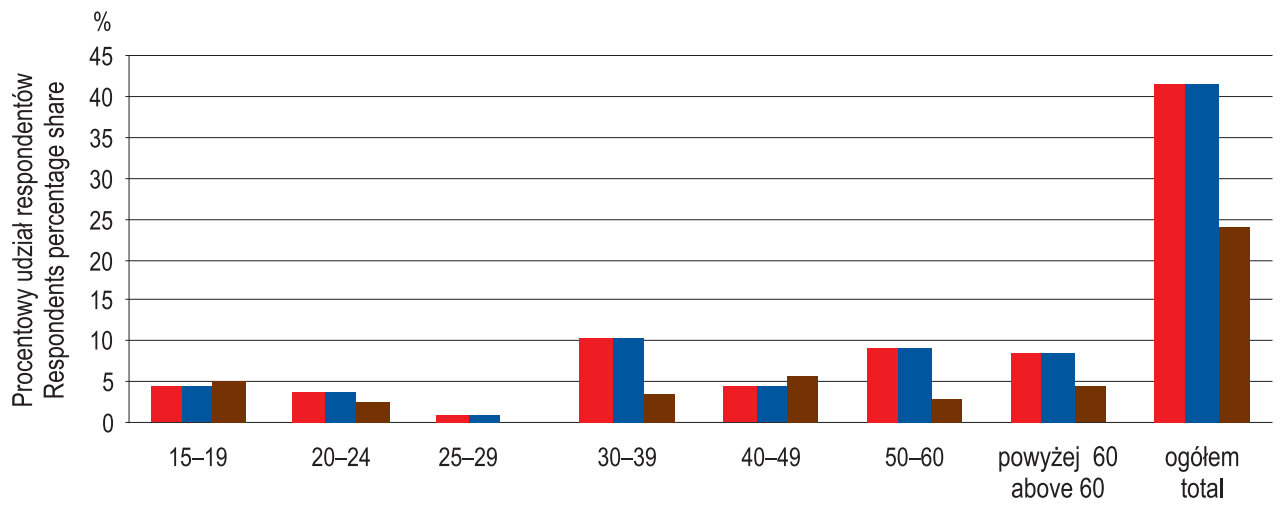

Wiek respondentów / Respondents age

Klimat, pogoda, egzotyka miejsca / Climate, weather, exotics of the place

Czas dojazdu / Travel time

Walory turystyczne (nieskażona przyroda, cisza, spokój) / Tourist attractions (unspoilt nature, quiet, peace)

Ryc. 3. Znaczenie takich czynników, jak: klimat, pogoda, egzotyka miejsca, czas dojazdu oraz walory turystyczne (nieskażona przyroda, cisza, spokój) w wyborze destynacji turystycznej Fig. 3. Importance of factors such as climate, weather, exotics of the place, travel time and tourist attractions (unspoilt nature, quiet, peace)

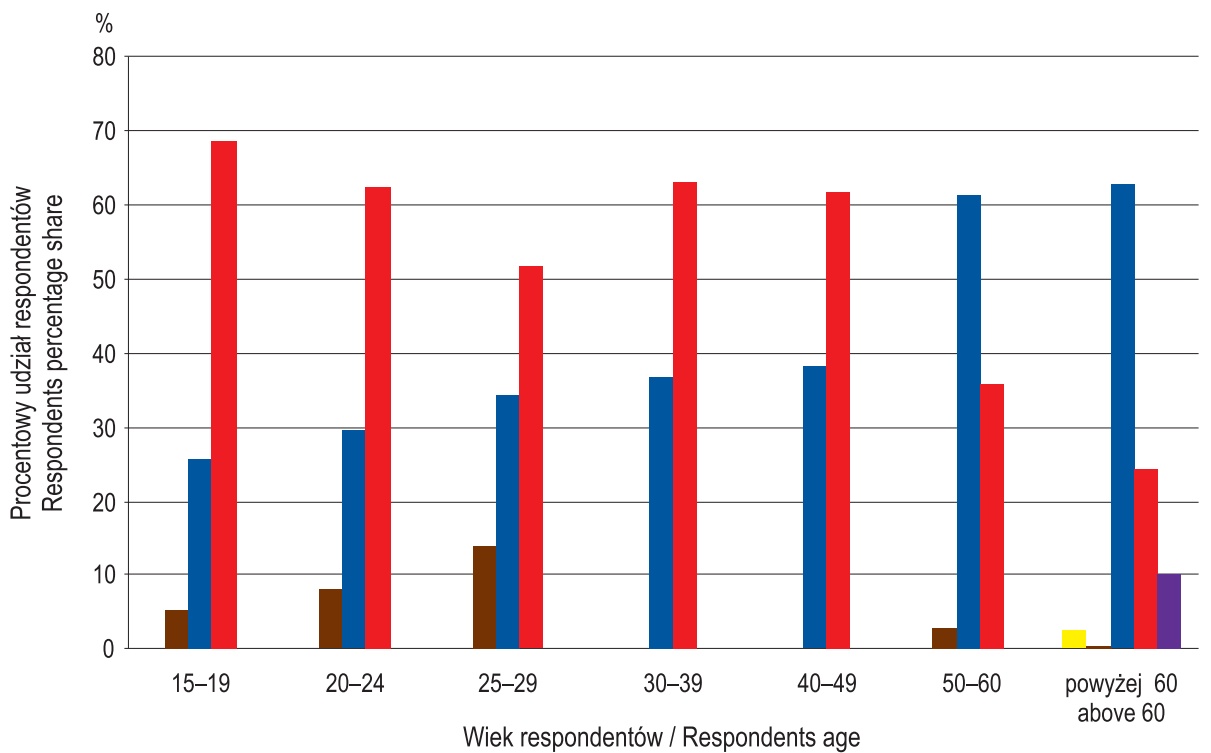

Prom / Sea ferry $\square$ Pociag / Train $\square$ Samolot / Plane Samochód / Car $\square$ Inne / Other

Ryc. 4. Wybór środka transportu (\%)

Fig. 4. Choosen mode of transport (\%) 
odpowiedzi udzieliło zaledwie 2,4\% osób w wieku powyżej 60 lat, co stanowi jedynie 0,5\% ogólnej liczby udzielonych odpowiedzi we wszystkich grupach wiekowych. Polonia chicagowska równie rzadko podróżuje pociągiem (3\%) oraz autokarem, z którego korzysta jedynie 10,2\% w grupie wiekowej powyżej 60 lat, co w ogólnej liczbie odpowiedzi dało 2,1\%. Autokar wykorzystują oni głównie jako środek transportu podczas wyjazdów pielgrzymkowych (ryc. 4).

Samochód był najczęściej wybieranym środkiem transportu $(50,6 \%)$, z tego względu, że bliskie podróże krótkoterminowe, z jednym noclegiem, często też nazwane wyjazdami weekendowymi, odbywają się w obrębie stanu Illinois, w którym leży Wielka Metropolia Chicagowska, oraz do sąsiednich stanów. W przeprowadzonych badaniach wyraźnie widać, że samochód częściej wybierają osoby młode, których nie stać na podróż samolotem.

$\mathrm{Na}$ drugim miejscu wśród udzielonych odpowiedzi $(43,9 \%)$ znalazł się samolot. Jest to najczęstszy środek lokomocji wybierany przez osoby w wieku powyżej 60 . roku życia (62,6\%) oraz osoby w przedziale wiekowym 50-60 lat (61,4\%). Wybór ten jest związany zapewne z lepszą sytuacją materialną tych osób oraz chęcią zobaczenia dalszych, odległych miejsc, do których trzeba dotrzeć samolotem. Ważnym aspektem dla tych osób, z uwagi na to, że mają oni mało czasu, który mogą przeznaczyć na urlop, jest również czas dojazdu do miejsca wypoczynku. Badania pokazały, że jedną z głównych destynacji zagranicznych wybieranych przez Polonię zamieszkującą Wielką Metropolię Chicagowską są Meksyk oraz Karaiby. Popularność tych miejsc wśród chicagowskiej Polonii podyktowana jest zapewne modą, ale również szybkością dotarcia do miejsca wypoczynku.

W ostatnich latach bardzo popularnym zjawiskiem w turystyce, zwłaszcza wśród Amerykanów i chicagowskiej Polonii, jest tzw. podróżowanie po południku. Polega ono na tym, że na miejsce wypoczynku wybierane są destynacje, do których dotrzeć można z lokalnego lotniska w ciągu 2-3 godzin, nie zmieniając przy tym strefy czasowej. Czas dojazdu znalazł się na szóstym miejscu (27\% odpowiedzi) wśród czynników, które decydują o aktywności turystycznej oraz wyborze destynacji turystycznych wśród chicagowskiej Polonii.

\section{Podsumowanie}

Wpisując się w nurt geograficznych badań nad aktywnością turystyczną i wyborami destynacji turystycznych Polonii mieszkającej w Wielkiej Metropolii Chicagowskiej, podjęto tematykę kompleksowej analizy najistotniejszych uwarunkowań tego zjawiska. Starano się tym samym podjąć nowy problem w dziedzinie geografii społecznej. Przeprowadzone badania wykazały, że turystyka odgrywa dużą rolę wśród chicagowskiej Polonii i jest to aktywna turystycznie grupa społeczna. 
Prowadzone badania dotyczące aktywności turystycznej polskich emigrantów w USA są pionierskie. Dotychczas podobnych i tak rozbudowanych badań nie było. Znane jest opracowanie Stadnik (2012), autorki artykułu pt. Aktywność turystyczna Polonii kanadyjskiej na przykładzie miesskańców Vancouver. Badania te dotyczyły przestrzennej organizacji czasu wolnego mieszkańców miasta Vancouver i zostały przeprowadzone na wybranej części tej społeczności, którą stanowią osiedleni tam Polacy. Główną problematyką badań była próba ustalenia poziomu i struktury aktywności turystycznej Polonii w Vancouver, z uwzględnieniem specyfiki zamieszkiwanego obszaru. Zakres czasowy przeprowadzonych badań obejmował 2008 r. Podczas analizy aktywności turystycznej Polonii w Kanadzie wykorzystano takie czynniki jak: płeć, wiek, wykształcenie, zawód, osiągnięty poziom materialny oraz liczba dzieci.

W niniejszym artykule postawiona hipoteza badawcza mówiąca o tym, że miejsce zamieszkania chicagowskiej Polonii (czynnik geograficzny) w Wielkiej Metropolii Chicagowskiej wpływa na częstość wyjazdów, długość ich trwania oraz wybór destynacji turystycznych została potwierdzona w badaniach statystycznych i tym samym: - osoby mieszkające poza miastem Chicago (na przedmieściach) częściej podróżują niż osoby mieszkające w Chicago. Na podstawie wypowiedzi respondentów można stwierdzić, że osoby mieszkające w mieście Chicago jako miejsce wypoczynku częściej wybierają wieś niż osoby mieszkające na przedmieściach;

- wypoczynek osób mieszkających poza miastem Chicago w ciągu roku trwa dłużej niż osób mieszkających w Chicago;

- osoby mieszkające poza miastem Chicago częściej niż osoby mieszkające w Chicago wybierają zagraniczny urlop. Jak pokazały badania, może to być spowodowane faktem, że osoby mieszkające poza miastem Chicago są bardziej zamożnymi osobami od tych mieszkających w samym mieście Chicago.

Konsekwencją dotychczasowych rozważań na temat związków turystyki i środowiska geograficznego oraz ich uwarunkowań jest podział, a może nawet klasyfikacja geograficzna turystyki. Niemal każdy podręcznik turystyki zawiera własną lub modyfikowaną klasyfikację tego zjawiska. Podział ruchu turystycznego będącego synonimem turystyki dokonuje się w oparciu o różne kryteria, wśród których najczęściej są wykorzystywane: motywy (cele) wyjazdów, czas ich trwania, formy turystyki, zasięg geograficzny, struktury demograficzne i społeczne, środki transportu i inne. Rozwój turystyki światowej, regionalnej lub lokalnej jest uzależniony geograficznie, bowiem turystyka jest przede wszystkim zjawiskiem przestrzennym polegającym na przemieszczaniu się człowieka (w określonych celach) w zróżnicowanej przestrzeni geograficznej.

Głównym problemem badań była próba ustalenia poziomu aktywności turystycznej chicagowskiej Polonii z uwzględnieniem specyfiki zamieszkiwanego obszaru. Jak wykazały przeprowadzone badania, czynniki geograficzne wpływają na aktywność turystyczną i wybór destynacji turystycznych wśród badanej grupy respondentów. 
Analiza uzyskanych wyników umożliwiła odpowiedź na postawione pytania badawcze. Podsumowując, można stwierdzić, że dla Polonii z Wielkiej Metropolii Chicagowskiej, obejmującej poza miastem Chicago sześć przylegających do miasta hrabstw, znaczącym czynnikiem decydującym o wyborze kierunku jest czas dojazdu i tzw. podróżowanie po południku, które pozwala podróżnemu na pozostanie w takiej samej strefie czasowej w stosunku do jego miejsca zamieszkania. Ankietowani mieszkający w hrabstwach leżących w obrębie Wielkiej Metropolii Chicagowskiej częściej podróżują w ciągu roku, wybierają zagraniczne destynacje jako kierunek swoich wyjazdów oraz ich wypoczynek trwa dłużej niż przebadanej grupy społecznej mieszkającej w samym mieście Chicago.

Od wielu lat Polacy, którzy nie chcą na stałe mieszkać w samym mieście Chicago, ale wolą przebywać względnie blisko miasta, przeprowadzają się na tereny podmiejskie, tzw. suburbia. W ostatnich dziesięcioleciach zaobserwowano zjawisko ucieczki majętniejszej części ludności miasta na jego przedmieścia.

\section{Literatura}

Alejziak W., 1990, Uwarunkowania aktywności turystycznej mieszkańców wsi [w:] Wieś i rolnictwo, PAN - Instytut Rozwoju Wsi i Rolnictwa, Warszawa, 1 (66), 197-208.

Alejziak W., 2009, Determinanty i zróżnicowanie spoteczne aktywności turystycznej, Wydawnictwo AWF, Kraków.

Aplleberg M.J., 1993, I Love Chicago Guide, Collier Books, New York.

Babiński G., 2012, Polskie zbiorowości emigranckie wczoraj i dziś-sto lat różnicy, ile podobieństw,

Biuletyn Migracyjny - Dodatek, 36. [http://biuletynmigracyjny.uw.edu.pl/dodatek-36-czerwiec-2012/polskie-zbiorowosci-emigranckie-wczoraj-i-dzis-sto-lat-roznicy-ile-podobien]. (dostęp: 17.01.2019)

Berlińska-Dzikowska R., Majewska-Śliwa M., Bosiacki S., 1987, Wyjazdy turystyczne ludności Polski w 1985 roku $i$ wwiqæane z nimi wydatki, Instytut Turystyki, Warszawa.

Blalock H.M., 1987, Statystyka dla socjologów, Wydawnictwo Naukowe PWN, Warszawa.

Boniface B.G., Cooper Ch., 1994, Worldwide destinations, The Geography of Travel \& Tourism, Butterworth-Heinemann, Oxford.

Burkart A.J., Medlik S., 1981, Tourism: past, present and future, Heinemann, London.

Creaton S., 2004, How a small Irish Airline conquered Europe, Aurum Press, London.

Deja W., 1986, Wptyw środowiska przyrodniczego na zróżnicowanie turystycznych form rekreacji, Wydawnictwo AWF, Warszawa, 106-130.

Delekta A., 2013, Determinanty aktywności i destynacji turystycznych studentów dużego i matego ośrodka akademickiego, Wydawnictwo Naukowe Uniwersytetu Pedagogicznego w Krakowie, Kraków. Drzewiecki M., 1998, Pojęcie turystyki wiejskiej, Turyzm, 1, 21-27.

Dziekońska M., 2008, Migracje podlaskich elit intelektualnych do USA - spojrzenie na American Dream [w:] M. Dajnowicz (red.), Oblicze polityczne regionów Polski, Wydawnictwo Wyższej Szkoły Finansów i Zarządzania w Białymstoku, Białystok, 89-102. 
Dziedzic E., 2000, Promocja regionu a decyzje nabywców [w:] A. Szwichtenberg, W. Deluga (red.), Rola marketingu w rozwoju regionów turystycznych, Wydawnictwo Politechniki Koszalińskiej, Koszalin.

Fiń A., 2014, Wspótczesna polska emigracja w Stanach Zjednoczonych: skala, rozmieszczenie przestrzenne, przyczyny wyjazdu, Studia Migracyjne - Przegląd Polonijny, 105-130.

French C.N., Craig-Smith S.J., Collier A., 1995, Principles of Tourism, Longman, Melbourne, 292-306.

Glaser B.G., Strauss, A.L., 2009, Odkrywanie teorii ugruntowanej. Strategie badania jakościowego, Nomos, Kraków.

Iglicka K., 2008, Kontrasty migracyjne Polski: Perspektywa transatlantycka, Wydawnictwo Naukowe Scholar, Warszawa.

Konecki K.,2000, Studia z metodologii badań jakościowych. Teoria ugruntowana, PWN, Warszawa.

Kowalczyk A., 1994, Doświadczenia i przesycia zwiqzane z krajobrazem a skuteczność wypoczynku [w:] W. Deja (red.), Turystyka jako czynnik edukacji i rozwoju spoteczno-gospodarczego, Poznań.

Kożuchowski K., 2005, Walory przyrodnicæe w turystyce i rekreacji, Wydawnictwo Kurpisz, Poznań.

Kymlicka W., 1999, Liberal Complacencies [w:] J. Cohen, M. Howard, M.C. Nussbaum (red.), Is multiculturalism bad for women, Princeton University Press, Princeton, 31-34.

Liszewski S., 1995, Præestræen turystyczna, Turyzm, 5 (2), 87-103.

Liszewski S., 2003, Wkład geografii w rozwój turystyki w Polsce [w:] G. Gołembski (red.), Kierunki rozwoju badań naukowych w turystyce, Akademia Ekonomiczna w Poznaniu, Wydawnictwo Naukowe PWN, Warszawa, 111-121.

Liszewski S., 2005, Koncepcja sintegrowanych badań nad turystykq [w:] B. Domański, S. Skiba (red.), Geografia i sacrum, t. 2, Instytut Geografii i Gospodarki Przestrzennej Uniwersytetu Jagiellońskiego, Kraków, 105-113.

Liszewski S., 2009, Geograficzne uwarunkowania turystyki, Uniwersytet Łódzki, Instytut Geografii Miast i Turyzmu, 9-23.

Lubowicz Z., 1996, Turystyka młodzie:̇y szkót ponadpodstawowych w 1995, Problemy Turystyki, $1-4,105-110$.

Łopaciński K., 1988, Poziom aktywności turystycznej studentów [w:] J. A. Malinowski (red.), Spoteczno-pedagogiczne problemy turystyki, Instytut Turystyki, Warszawa.

Matczak A., 1992, Model badań ruchu turystycznego. Studium metodologiczne, Acta Universitatis Lodziensis - Folia Geographica, 8, Wydawnictwo Uniwersytetu Łódzkiego, Łódź.

Meyer B., 2004, Turystyka jako ekonomiczny czynnik ks:tałtowania præestrzeni, Uniwersytet Szczeciński, Szczecin, 173-180.

Milewski D., 2008, Przewozy turystyczne [w:] A. Panasiuk (red.), Gospodarka turystyczna, Wydawnictwo Naukowe PWN, Warszawa, 147-163.

Młynarczyk Z., Zajadacz A. (red.), 2008, Przyrodnicze sasoby turystyki i metody ich oceny. Uwarunkowania i plany rozwoju turystyki, Seria: Turystyka i Rekreacja - Studia i Prace, t. 2, Wydawnictwo Naukowe UAM, Poznań. 
Niezgoda A., 2006, Obszar recepcji turystycznej w warunkach rozwoju zrównoważonego, Wydawnictwo UE w Poznaniu, Poznań.

Nowakowska A., 1989, Spoteczno-ekonomicæne wwarunkowania ruchu turystycænego w uktadach præestræennych, Zeszyty Naukowe, Seria: Monografie, 88, Akademia Ekonomiczna w Krakowie, Kraków.

Paral R., Norkiewicz M., 2004, Metro Chicago immigration fact book, Roosevelt University, Chicago.

Parzych K., 2008, Zró̈nicowanie præestrzenne zagranicznych destynacji turystycænych mtodzieży na przyktadzie wyjazdów turystycznych mtodzieży licealnej Stupska i Cięstochowy, Turystyka i Hotelarstwo, 14, 53-67.

Pearce D.G., 1995, Tourism today: A geographical analysis (2nd ed.), Longman Scientific \& Technical, Harlow.

Pedro A., 2006, Urbanization and second-home tourism [w:] D. Buhalis, C. Costa (red.), Tourism Management Dynamics - consumers products and industry, Elsevier, 63-74.

Rettinger R., Staszak P., 2010, Europejskie potqczenia lotnicze głównych regionów turystycznych Aжji Potudniowo-Wschodniej [w:] Z. Zioło, T. Rachwał (red.), Przedsiębiorczośc-Edukacja, 6, Wydawnictwo Nowa Era Sp. z o.o., Warszawa-Kraków, 462-470.

Rogalewski O., 1974, Zagospodarowanie turystyczne, WSiP, Warszawa.

Rokicki J., 1989, Wakacjusze na Jackowie i inni. Szkic o sytuacji wspótczesnych polskich emigrantów zarobkowych w Chicago, Przegląd Polonijny, 2, 105-118.

Rokicki J., 1992a, Pegaz nad polskim Chicago, Świat Polonii.

Rokicki J., 1992b, Więźspoteczna a zmiana kultury. Studium dynamiki polskiej zbiorowości etnicznej w USA, Zakład Narodowy im. Ossolińskich, Wrocław.

Różycki P., 2006, Determinanty aktywności turystycznej mtodzieży, Problemy Turystyki, 1-4, $157-166$.

Sakson B., 2007, Wspótcześni polscy emigranci w metropolii Chicago, Przegląd Polonijny, 2, 181-201.

Silverman D., 2007, Interpretacja danych jakościowych. Metody analizy rozmowy, tekstu, interakcji, PWN, Warszawa.

Skórny Z., 1989, Mechanizmy regulacyjne ludzkiego działania, Wydawnictwo Naukowe PWN, Warszawa.

Sojka E., 2003, Statystyka w przyktadach $i$ æadaniach. Podręcznik akademicki, Śląskie Wydawnictwa Naukowe Wyższej Szkoły Zarządzania i Nauk Społecznych, Tychy.

Stadnik K., 2012, Aktywność turystyczna Polonii kanadyjskiej na przykładzie mieszkańców Vancouver, Zeszyty Naukowe Uniwersytetu Szczecińskiego, Prace Instytutu Kultury Fizycznej, 28, 223-236.

Stemplewska-Żakowicz K., 2010, Metody jakościowe, metody ilościowe: hamletowski dylemat czy różnorodność do wyboru? Roczniki Psychologiczne, 1 (13), 87-96.

Travis A.S., 1989, Tourism destination area development [from theory into practice) [w:] F. Witt, L. Moutinho (red.), Tourism marketing and management handbook, Prentice Hall, New York, 487-498. 
Um S., Crompton J.L., 1990, Attitude determinants in tourism destination choice, Annals of Tourism Research, 17 (3), 432-448.

Wasiakowa H., 1982, Zró̋̇nicowanie poziomu konsumpcji w dziedzinie turystyki i wypoczynku w makroregionach [w:] J. Olearnik, J. Prudzienica (red.), Gospodarka turystyczna - rynek i konsumpcja ustug turystycznych, Wydawnictwo Uczelniane Akademii Ekonomicznej, Wrocław.

Włodarczyk B., 1999, Præemiany form aktywności turystycznej. Przykład krawędzi Wyżyny Łódzkiej, Łódzkie Towarzystwo Naukowe, Łódź, 89-97.

Włodarczyk B., 2009, Przestræen turystyczna. Istota, koncepcje, determinanty rozwoju, Wydawnictwo UŁ, Łódź.

Viner D., Nichols S., 2006, Climate change and its implications for international tourism [w:] D. Buhalis, C. Costa (red.), Tourism management dynamics - trends, management and tools, Elsevier, Oxford, 1-24.

Ziółkowska-Weiss K., 2013, Oferta lotniska Kraków-Balicew rozwoju gospodarki opartej na wiedzy. Przyktad zmian w infrastrukturze transportowej, implikacje dla rozwoju turystyki [w:] Z. Zioło, M. Borowiec (red.), Wybrane problemy rozwoju ustug turystycznych, Prace Komisji Geografii Przemysłu Polskiego Towarzystwa Geograficznego, 24, 91-106.

Ziółkowska-Weiss, K., 2018, Przestrzenne rozmieszczenie Polonii w Wielkiej Metropolii Chicagowskiej [w:] D. Praszałowicz (red.), Studia Migracyjne - Przeglad Polonijny, Migration Studies-Review of Polish Diaspora, Komitet Badań nad Migracjami, 1(167), 49-68.

\section{Raporty}

Yearbook of Immigration Statistic, 2013, Homeland Security [https://www.dhs.gov/immigration-statistics/yearbook/2013] (dostęp: 2.04.2019).

Census Bureau, 2013, Summary File 4(SF4) - Sample Data PCT1, Ancestry-Polish, U.S. Census Bureau [https://www.census.gov/prod/cen2000/doc/sf4.pdf] (dostęp: 2.04.2019).

Rocznik Statystyczny Rzeczypospolitej Polskiej GUS, 2013.

\section{Strony internetowe}

https://commons.wikimedia.org/wiki/File:Map_of_Cook_County_Illinois_showing_townships.png, (dostęp: 05.04.2019r.).

Kamila Ziótkowska-Weiss

Uniwersytet Pedagogicwny w Krakowie

Instytut Geografii

Zaktad Turystyki i Badan Regionalnych

ul. Podchorqżych 2, 30-084 Kraków

kamilazw@up.krakow.pl 